\title{
Colonization of Streptomyces felleus YJ1 and Its Effects on Disease Resistant-Related Enzymes of Oilseed Rape
}

\author{
Guanglong Cheng ${ }^{1 *}$, Fan Liu ${ }^{2 *}$, Yun Huang ${ }^{1}$, Hui Yang ${ }^{1}$, Jia Yao ${ }^{1}$, Huirong Shen ${ }^{1} \& \mathrm{Jie} \mathrm{Xu}^{1}$ \\ ${ }^{1}$ Department of Plant Pathology, Sichuan Agricultural University, Wen'jiang, Sichuan Province, China \\ ${ }^{2}$ Department of Plant Pathology, Guangxi Botanical Garden of Medicinal Plants, Nan'ning, Guangxi Province, \\ China \\ Correspondence: Yun Huang, Department of Plant Pathology, Sichuan Agricultural University, Wen'jiang \\ 611130, Sichuan Province, China. E-mail: 5787huangyun@sina.com.cn \\ * These authors contributed equally to this work
}

Received: January 17, 2014 Accepted: February 18, 2014 Online Published: April 15, 2014

doi:10.5539/jas.v6n5p26 URL: http://dx.doi.org/10.5539/jas.v6n5p26

\begin{abstract}
Streptomyces felleus YJ1 has strong antagonism against Sclerotinia sclerotiorum, and it can be used for preventing this fungal disease in oilseed rape in the greenhouse. Under greenhouse conditions, we determined the colonization dynamic variation of $\mathrm{YJ} 1$ in soil and rape; and the changes of defensive enzymes of rape induced by $\mathrm{YJ} 1$ were measured. The results showed that, YJ1 could colonize chronically in soil; and it could also colonize in roots of rape and conduct to the stem and leaves, suggesting good colonization potential. After the rapes were processed by YJ1 fermentation liquid broth, the changes of defensive enzymes (SOD, PPO, POD etc.) in rape were measured. The results showed that, the activities of defensive enzymes changed significantly, especially in the four days later, the SOD, POD, PPO and PAL activities were significantly higher than that of inoculated with S. sclerotiorum and control, and maintained at a high level. Those results indicated that induced systemic resistance of rape maybe one of antagonistic mechanism of YJ1 against S. sclerotiorum.
\end{abstract}

Keywords: Streptomyces felleus, oilseed rape, colonization, disease resistant-related enzymes

\section{Introduction}

Sclerotinia stem rot, caused by the pathogen Sclerotinia sclerotiorum (Lib.) de Bary, is one of the most serious diseases of oilseed rape (Ding et al., 2013). S. sclerotiorum is a kind of devastating worldwide pathogens and it can infect tomato, rapeseed, sunflower, soybean, broad beans, lettuce and many other economically important crops, besides its sclerotium that can survive for up to 8 years in soil has very strong resistance (Hegedus \& Rimmer, 2005; Lamey, 2003; Bae \& Knudsen, 2007). Oilseed rape is an important oil crop around the world, however the yield and quality of rape can be seriously affected by S. sclerotiorum, and the yield loss can be $10 \% \sim 80 \%$ (Zhao \& Meng, 2003; Ma et al., 2009). For the prevention of S. sclerotiorum, chemical control is the most commonly used strategy (Mueller et al., 2002). But using chemicals can cause environmental problems, and has negative influence on food safety, the health of human beings, etc (Demoz \& Korsten, 2006; Inbar, Menendez, \& Chet, 1996). Therefore, many researchers have turned to studying using antagonistic microorganisms to prevent against S. sclerotiorum.

Presently, the research results have certificated that there are at least more than 30 kinds of fungi, bacteria or other microorganisms which have good control effects against S. sclerotiorum (Gao et al., 2010; Li et al., 2003; Chen et al., 2001; Jiang et al., 2000). Several species of Bacillus and Pseudomonas have been successfully used to control the fungus (Fernando et al., 2007); the mycoparasites Trichoderma spp. are the most used and studied, because they can effectively reduce the ascospores and sclerotia (Abdullah et al., 2008). They are widely used commercially and certified as available strains (Elad, 2000). In addition, actinomycetes (mainly Streptomyces) have also been reported for the control of $S$. sclerotiorum, because they can produce a variety of antibacterial substances and different types of lytic enzymes (chitinase, cellulase, endoglucanase etc.) that have inhibitory effects on many phytopathogens (Clardy et al., 2006; El-Tarabily et al., 1997). Streptomyces spp. 80, chitinase 
producing Streptomyces, Propionicimonas sp. ENT-18, etc. were available to prevent Sclerotinia sclerotiorum (Fróes et al., 2012; Tahtamouni et al., 2006; Zucchi et al., 2010).

The colonization and adaptation of biocontrol bacteria in a certain environment, as well as good affinity ability in the target crops, is the key for that biocontrol strains to play the biocontrol effect effectively (Kloepper, 1992; Hu et al., 2009; Sturz et al., 1997). Inducing plant system resistance is one of the main antagonistic mechanisms of biocontrol bacteria. When plants are invaded by pathogens, their defense enzymes system [superoxide dismutase (SOD), peroxidase (POD), polyphenol oxidase (PPO), phenylalanine ammonia lyase (PAL) etc.] will be activated, and participate in various physiological metabolic processes, so that plant disease resistance responses are stimulated for preventing the invasion of pathogens (Kim et al., 2007). SOD, POD, PPO and PAL are closely related with plant disease resistance. SOD is endogenous active oxygen scavenger in plants and associated with lignin synthesis, and it can enhance plant resistance to pathogens (Dou et al., 2010); POD can catalyze the formation of lignin, thickening of plant cell wall to prevent bacteria invasion, meanwhile it also maintains the balance of active oxygen metabolism and protect the membrane structure in plants (Joseph et al., 1998); PAL is the key and rate limiting enzyme that participate in producing phytoalexin, lignans, phenolic compounds, and it was closely related with plants' system resistance (Wang \& Zhu, 2002; Xue \& Ouyang, 1992); Phenolic compounds can be oxidated by PPO into quinones materials that have inhibitory or killing effects on pathogens, and PPO is also involved in lignin formation (Wang et al., 2005; Volpin et al., 1995). Bacillus subtilis BY-2 can colonize in rape and be used for controlling Sclerotinia sclerotiorum effectively (Jiang et al., 2007). The Streptomyces spp.47W08, 47W10 etc., could be used as preventive biocontrol agents against Phytophthora capsici, and they could colonize in pepper roots while they were mixed with $P$. capsici in the inoculation; besides they could induce the improvement of PAL, PPO activities in the leaves of capsicum (Liang et al., 2005). Biocontrol agent XB16 which had a strong antagonism against Fusarium oxysporum colonized in banana plant commendably, and it could induce the activities of defense enzymes significantly increased (Sun et al., 2010).

The actinomycete strain YJ1 which was identified as Streptomyces felleus, was isolated from branches of Ginkgo and stored in our laboratory. It had significant effects by using this antagonistic actinomyces to control $S$. sclerotiorum in laboratory, greenhouse and field trials (Yao, 2010). In this study, we tried to explore the colonization potential of $S$. felleus YJ1 and the changes of disease resistant-related enzymes activities in rape induced by YJ1, so that it has had a further theoretical basis for that $S$. felleus YJ1 could be used for biocontrol practice.

\section{Materials and Methods}

\subsection{Strains, Culture Conditions and Medium}

Streptomyces felleus YJ1 was provided by the plant pathology laboratory in Sichuan Agricultural University. Sclerotinia sclerotiorum was isolated from the sclerotia formed in the stem of diseased rape from Wenjiang, China.

S. felleus was maintained and preserved on Gause's medium No.1; Gause's liquid medium and millet liquid medium were used for cultivating bacteria liquid of YJ1. S. sclerotiorum was maintained on Potato Dextrose Agar (PDA). They were both stored at $4^{\circ} \mathrm{C}$ until required.

The medium compositions were as follows:

Gause's medium No.1 contained: soluble starch 20.0 g, $\mathrm{KNO}_{3} 1.0 \mathrm{~g}, \mathrm{NaCl} 0.5 \mathrm{~g}, \mathrm{~K}_{2} \mathrm{HPO}_{4} 0.5 \mathrm{~g}, \mathrm{MgSO}_{4} \cdot 7 \mathrm{H}_{2} \mathrm{O} 0.5$ $\mathrm{g}, \mathrm{FeSO}_{4} \cdot 7 \mathrm{H}_{2} \mathrm{O} 0.01 \mathrm{~g}$, agar $20 \mathrm{~g}$, distilled water $1000 \mathrm{~mL}$, pH 7.2.

PDA medium contained: potato $200 \mathrm{~g}$, glucose $20 \mathrm{~g}$, agar $18 \sim 20 \mathrm{~g}$, distilled water $1000 \mathrm{~mL}$.

Gause's liquid medium contained: the same as Gause's medium No.1 except agar.

Millet liquid medium: millet $10.0 \mathrm{~g}$, glucose $10.0 \mathrm{~g}$, peptone $3.0 \mathrm{~g}, \mathrm{NaCl} 2.0 \mathrm{~g}, \mathrm{CaCO}_{3} 2.0 \mathrm{~g}$, distilled water 1000 $\mathrm{mL}, \mathrm{pH}$ 7.2-7.4.

\subsection{YJ1 Colonization}

\subsubsection{Streptomycin-Resistant Marker Strains}

The strain YJ1 was incubated on Gause's medium No.1 which was added $20 \mu \mathrm{g} / \mathrm{mL}$ streptomycin, gradually with increasing streptomycin concentration until at the maximum concentration used $(500 \mu \mathrm{g} / \mathrm{mL})$. Every time the concentration was increased by $20 \mu \mathrm{g} / \mathrm{mL}$. Then the mutation frequency, the physiological characteristics of the mutant strain and its inhibition effects against $S$. sclerotiorum were checked. Finally, the mutant strains were incubated in the flasks that contained Gause liquid medium added with $500 \mu \mathrm{g} / \mathrm{mL}$ streptomycin. The flasks were 
put in the dark at $28^{\circ} \mathrm{C}$ on a rotary shaker at $180 \mathrm{r}$. $\min ^{-1}$ for 7 days. The bacteria concentration was adjusted to $2.5 \times 10^{7} \mathrm{cfu} / \mathrm{mL}$. The bacterial suspension was stored at $4^{\circ} \mathrm{C}$ until required.

\subsubsection{Determination of Colonization in Soil}

The sterilized soil (the soil was collected from rhizosphere of oilseed rape) was arranged in the flowerpots (diameter $10 \mathrm{~cm}$ ), every pot $1.5 \mathrm{~kg}$ soil, and then each pot was injected bacterial suspension of YJ1 $10 \mathrm{~mL}$, and all the pots were incubated at room temperature. Streptomycin-Resistant strains were separated from the soil every eight days, and then we made the determination of colonization. The experiments were repeated 3 times.

\subsubsection{Determination of Colonization in Oilseed Rape}

The oilseed rapes (Mianyou 16) were planted in the greenhouse. When the plants had 5 7 leaves, we inoculated YJ1 by applying a soil drench with $10 \mathrm{~mL}$ YJ1 suspension. Then we started sampling rape roots, stem and leaf tissues once per 15 days after one month and separated the Streptomycin-Resistant strains. Next, we determined the colony count of YJ1 and calculated per gram of bacteria content in the plant tissues.

\subsection{Effect of YJI on Resistant-Related Enzyme Activity of Rape}

\subsubsection{Fermentation Broth Preparation}

YJ1 was inoculated into millet liquid medium in $250 \mathrm{~mL}$ flasks. The flasks were incubated in the dark at $28^{\circ} \mathrm{C}$ on an eberbach rotary shaker at $160 \mathrm{r}$. min $^{-1}$ for 7 days to obtain the fermentation broth, and then adjusted bacteria concentration to $2.5 \times 10^{7} \mathrm{cfu} / \mathrm{mL}$. The fermentation broth was stored at $4^{\circ} \mathrm{C}$ until required.

\subsubsection{Inoculation and Sampling}

The oilseed rapes (Mianyou 16) were planted in the greenhouse. When the plants had 7 leaves, the plants were treated respectively as follows: the first group, added YJ1 fermentation broth to the pots, every pot $30 \mathrm{~mL}$; the second group, added distilled water $30 \mathrm{~mL}$ to each pot; the third group, added water $30 \mathrm{~mL}$ to each pot and inoculated with $S$. sclerotiorum. The experiments were repeated 3 times. After the oilseed rapes were treated for 0.5 hours, 2 days, 4 days, 6 days, 8 days, the rape seedling fresh leaves were gathered to measure enzymes activities.

\subsubsection{Determination of Enzymes Activity}

Took the leaves gathered in 2.3.2 back to the laboratory immediately, and respectively measured the SOD, POD, PPO, PAL enzymes activities. According to the methods of Li's, Wu's and Zhao's (Li, 2000; Wu, 2006; Zhao et al., 1998), the activities of SOD, POD, PPO and PAL were determined respectively.

\section{Results}

\subsection{Streptomycin-Resistant Marker Strains}

The strain YJ1 was incubated in Gause's medium No.1 which was added streptomycin, finally we got the mutant strain and its colony morphology was similar to the original strain, and its physiological characteristics and antagonistic effects against S. sclerotiorum remained unchanged nearly. Besides, when cultivated for 10 generations, the target strain was still resistant to $500 \mu \mathrm{g} / \mathrm{mL}$ streptomycin. Thus, it had the resistance marker trait.

\subsection{Colonization of YJ1 in Soil}

When $S$. felleus YJ1 was applied into the soil, the bacteria number had been increased, and the number rose slowly at the beginning, after 24 days increased rapidly, and the total number had reached $2.135 \times 10^{9} \mathrm{cfu} / \mathrm{g}$ in the 40 th day (Figure 1). Next, the number of YJ1 did not change much, relatively stable. Thus, S. felleus YJ1 could colonize permanently in soil. 


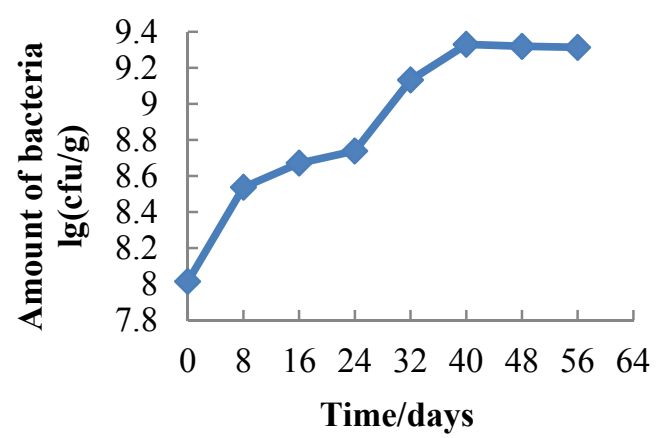

Figure 1. The colonization dynamics of biocontrol bacteria YJ1 in soil

$\lg (\mathrm{cfu} / \mathrm{g})$ respects the common logarithm of the measured data

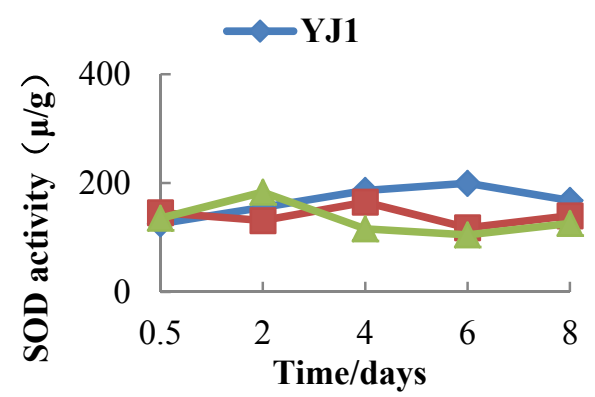

Figure 3. The change of SOD activity in leaves after fermentation liquid root irrigation and inoculated with S. sclerotiorum

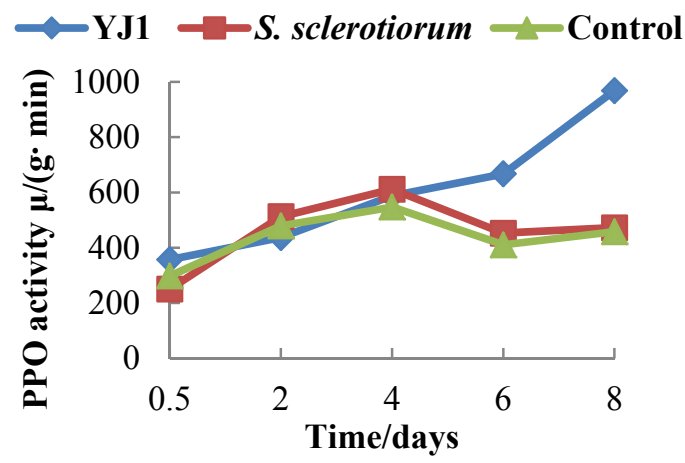

Figure 5. The change of PPO activity in leaves after fermentation liquid root irrigation and inoculated with S. sclerotiorum

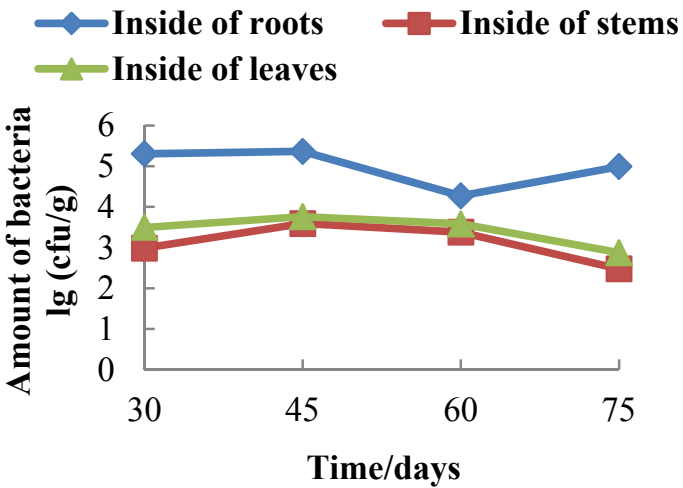

Figure 2. The colonization dynamics of biocontrol bacteria $\mathrm{YJ} 1$ in rapeseed

$\lg (\mathrm{cfu} / \mathrm{g})$ respects the common logarithm of the measured data

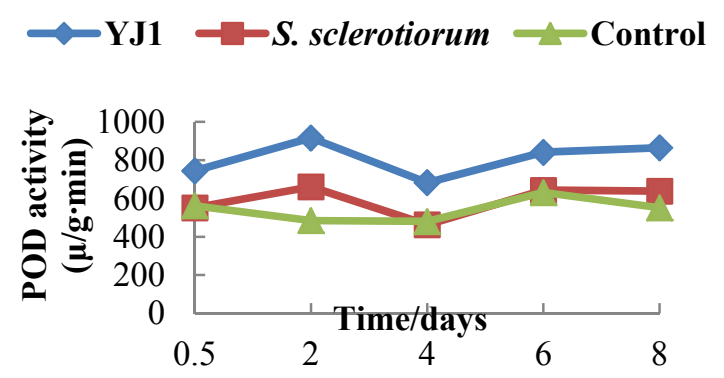

Figure 4. The change of POD activity in leaves after fermentation liquid root irrigation and inoculated with S. sclerotiorum

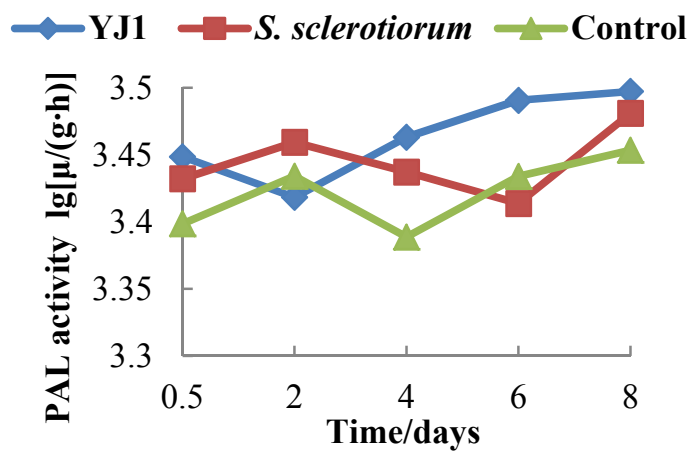

Figure 6. The change of PAL activity in leaves after fermentation liquid root irrigation and inoculated with S. sclerotiorum

$\lg [\mu /(g \cdot h)]$ respects the common logarithm of the measured data

Notes: Figure 3-6, YJ1 is treated by YJ1 fermentation broth; S. sclerotiorum is treated by S. sclerotiorum; and Control is treated by distilled water. 


\subsection{Colonization of YJ1 in Rape}

Inoculated with YJ1 by using the root drench method, the colonization of S. felleus YJ1 in rape was determined. The test results showed that, YJ1 could colonize in rape roots, and could conduct from the roots to the stem and leaves for colonization; the colonization number: root $>$ leaf $>$ stem (Figure 2). After the rapes were treated by YJ1 for 30 days, the number of that YJ1 colonized in rape roots increased slightly firstly, decreased next, and then increased; the number in stems and in leaves increased firstly, and then decreased. In the 75th day after the treatments, the quantity of $\mathrm{YJ} 1$ colonized in roots was $9.8 \times 10^{4} \mathrm{cfu} / \mathrm{g}$; the stem and roots were $3 \times 10^{2} \mathrm{cfu} / \mathrm{g}$ and $7.5 \times 10^{2} \mathrm{cfu} / \mathrm{g}$. Therefore, $S$. felleus $\mathrm{YJ} 1$ could colonize in rape for long time.

\subsection{Effect of S. felleus YJ1 on Enzyme Activity of Rape}

After treated by YJ1 fermentation liquid and inoculated with S. sclerotiorum, SOD, POD, PPO and PAL activities had significant changes. Treated by YJ1, SOD activity in rape leaves had a growth trend from the 0.5 day to 6 th day, and to the eighth day began to decline (Figure 3). Besides, SOD activity was obviously higher than that inoculated with $S$. sclerotiorum and control after the rapes were treated for 4 days. Compared with the control, SOD activity of inoculated with $S$. sclerotiorum was higher except the second day (Figure 3 ).

After the oilseed rapes were treated by $S$. felleus YJ1, POD activity was significantly higher than control and that inoculated with $S$. sclerotiorum (Figure 4). POD activity had the trend of increasing at the beginning of 2 days; and decreased from the second day to the 4th, from the 4th day to the 8th it showed increasing trend. Inoculated with $S$. sclerotiorum, POD activity had no significant difference in the processing of the day comparing with control, and reached $661.18 \mu /(\mathrm{g} \cdot \mathrm{min})$ in the second day; and the next the POD activity changed similarly to control.

After treated by $S$. felleus YJ1, PPO activity increased continuously and reached $968.38 \mu /(\mathrm{g} \cdot \mathrm{min})$ in the eighth day. There had no obvious difference between control and YJ1 before the starting four days; and PPO activity was significantly higher than that inoculated with S. sclerotiorum and control from the fourth day to the eighth. After inoculated with $S$. sclerotiorum, the change trend of PPO activity was the same as control, but the enzyme activity was much higher after the rapes were treated for two days (Figure 5).

After treated by $S$. felleus YJ1, PAL activity in rape leaves had decreased from 0.5 day to 2 days; and the next, the enzyme activity increased continuously and was significantly higher than control after 2 days, and much higher than that inoculated with $S$. sclerotiorum after 4 days. Compared with control, PAL activity of leaves inoculated with $S$. sclerotiorum had the same tendency from 0.5 day to fourth and from the sixth day to eighth; besides, PAL activity was almost higher than control (Figure 6).

\section{Discussion}

As biocontrol strains, the important premise of that they play a prevention role is that whether they can colonize stably in the target plants or their surroundings (Lian et al., 2011). Therefore, many scholars have measured and analyzed the colonization potential of biocontrol strains, understand the characteristic of the strains, to make prevention effects of the strains reached the maximum and make the strains used reasonably (Baudoin et al., 2002; $\mathrm{Hu}$ et al., 2009). Combined with antibacterial activity determination, some researchers also treat colonization ability as an important index of strain screening to improve the success rate of strains screening (Guo et al., 1996). The researchers, such as Lian (2011), Long and Xiao (2003), Li et al. (2006), had reported that colonization of antagonistic bacteria in target crops and the results showed those strains could colonize in roots, stems and rhizosphere, and especially colonization in the roots was stable; in addition, the colonization ability of the strains in roots was stronger than that in stems, leaves; and colonization at the bottom of the stems was better than that of the upper stems. Through this study, we got the similar results: the strain YJ1 was colonized and transferred in rape tissues, and it could also proliferate in colonization sites. Besides, YJ1 could colonize in soil for long time. When biocontrol strains distribute steadily in plants and rhizosphere, it is easier for biocontrol strains to have the prevention effects (Andrews, 1992). In short, YJ1 was displayed good colonization in oilseed rape.

When the plants invaded by pathogens, the resistant-related enzymes (SOD, POD, PPO and PAL etc.) are activated and participate in many physiological processes, such as oxidation, lignification, response to pathogenic toxin, to prevent the invasion and reproduction of the pathogens. Therefore, SOD, POD, PPO and PAL are closely related with plant disease resistance. Some researchers, such as Yi et al. (2007) and Liu et al., (2010), have showed that SOD, POD, PPO, PAL activities were significantly enhanced when the target crops were treated by biocontrol strains. In this study, after inoculated with YJ1 fermentation broth by using the root drench method, SOD, POD, PPO, PAL activities showed obvious fluctuations, especially after the treatment for 4 days the enzymes activities were significantly higher than those inoculated with S. sclerotiorum and control, and maintained at a high level. 
Those results indicated that induced systemic resistance of oilseed rape may be one of antagonistic mechanism of YJ1 against S. sclerotiorum.

Next, we can further study about antagonist material type of YJ1, development of agents and use methods etc, to ensure that this strain can be better used in biological control of Sclerotinia sclerotiorum.

\section{Acknowledgements}

The work was supported by "Commonweal Specialized Research Fund of Chinese Agriculture” (201103016) and research of technical solutions about $S$. sclerotiorum.

\section{References}

Abdullah, M. T., Ali, N. Y., \& Suleman, P. (2008). Biological control of Sclerotinia sclerotiorum (Lib.) de Bary with Trichoderma harzianum and Bacillus amyloliquefaciens. Crop Prot, 27, 1354-1359. http://dx.doi.org/10.1016/j.cropro.2008.05.007

Andrews, J. H. (1992). Biological control in the phyllosphere. Ann. Rev. Phytopathol, 30, $603-635$. http://dx.doi.org/10.1146/annurev.py.30.090192.003131

Bae, Y. S., \& Knudsen, G. R. (2007). Effect of sclerotial distribution pattern of Sclerotinia sclerotiorum on biocontrol efficacy of Trichoderma harzianum. Appl. Soil Ecol, 35, 21-24. http://dx.doi.org/10.1016/j.apsoil.2006.05.014

Baudoin, E., Benizri, E., \& Guckert, A. (2002). Impact of growth stage on the bacterial community structure along maize roots, as determined by metabolic and genetic fingerinting. Applied Soil Ecology, 19(2), 135-45. http://dx.doi.org/10.1016/S0929-1393(01)00185-8

Chen, B. Y., Zhou, Y. C., \& Lu, Z. P. (2001). Fermentation of Trichoderma viride and Suppression of Rapeseed Sclerotinia Stem Rot by the Fermentation Filtrate. Chinese Journal of Biological Control, 17(2), 67-70.

Clardy, J., Fischback, M. A., \& Walsh, C. T. (2006). New antibiotic from bacterial natural products. Nature Biotech, 24, 1541-1550. http://dx.doi.org/10.1038/nbt1266

Demoz, B. T., \& Korsten, L. (2006). Bacillus subtilis attachment, colonization, and survival on avocado flowers and its mode of action on stem-end rot pathogens. Biological Control, 37, 68-74. http://dx.doi.org/10.1016/j.biocontrol.2005.11.010

Ding, Y. J., Mei, J. Q., Li, Q. F., Liu, Y., Wan, H. F., Wang, L., .. Qian, W. (2013). Improvement of Sclerotinia sclerotiorum resistance in Brassica napus by using B. oleracea. Genet Resour Crop Evol, 60, 1615-1619. http://dx.doi.org/10.1007/s10722-013-9978-z

Dou, J. H., Yu, S. X., \& Fan, S. L. (2010). SOD and Plant Stress Resistance. Molecular Plant Breeding, 8(2), $359-364$.

Elad, Y. (2000). Biological control of foliar pathogens by means of Trichoderma harzianum and potential modes of action. Crop Prot, 19, 709-714. http://dx.doi.org/10.1016/S0261-2194(00)00094-6

El-Tarabily, K. A., Hardy, G. E. S. J., Sivasithamparam, K., Hussein, A. M, \& Kurtboke, D. I. (1997). The potential for the biological control of cavity-spot disease of carrots, caused by Pythium coloratum, by streptomycete and non-streptomycete actinomycetes. New Phytol, 137, 495-507. http://dx.doi.org/10.1046/j.1469-8137.1997.00856.x

Fernando, W. G. D, Nakkeeran, S., Zhang, Y., \& Savchuk, S. (2007). Biological control of Sclerotinia sclerotiorum (Lib.) de Bary by Pseudomonas and Bacillus species on canola petals. Crop Prot, 26, 100-107. http://dx.doi.org/10.1016/j.cropro.2006.04.007

Fróes, A., Macrae, A., Rosa, J., Franco, M., Souza, R., Soares, R., \& Coelho, R. (2012). Selection of a Streptomyces strain able to produce cell wall degrading enzymes and active against Sclerotinia sclerotiorum. The Journal of Microbiology, 50(5), 798-806. http://dx.doi.org/10.1007/s12275-012-2060-2

Gao, X. N., Chen, J. Y., \& Huang, L. L. (2010). Screening of antagonistic endophytic bacteria and their roles in control of Sclerotinia sclerotiorum. Chinese Journal of Pesticide Science, 12(2), 161-167.

Guo, J. H., Wang, Y. J., \& Li, J. (1996). Screen of biocontrol bacteria of plant wilt by inhibiting zones and root-colonization capacity. Acta Phytopathologica Sinica, 26(1), 49-54.

Hegedus, D. D., \& Rimmer, S. R. (2005). Sclerotinia sclerotiorum: When "to be or not to be" a pathogen? FEMS Microbiology Letters, 251, 177-184. http://dx.doi.org/10.1016/j.femsle.2005.07.040 
Hu, J. H., Zhang, F. J., \& Lan, X. Q. (2009). Analysis of the colonization of tobacco rhizosphere bacterium swu31-2 and its control effect on tobacco bacterial wilt. Plant Protection, 35(5), 89-94.

Inbar, J., Menendez, A. N. A., \& Chet, I. (1996). Hyphal interaction between Trichoderma harzianum and Sclerotinia sclerotiorum and its role in biological control. Soil Biol. Biochem., 28, 757-763. http://dx.doi.org/10.1016/0038-0717(96)00010-7

Jiang, D. H., Li, G. Q., Fu, \& Y. P. (2000). Biocontrol of reinfection of oilseed rape stem rot caused by Sclerotinia sclerotiorum BY coniothyrium minitans and its survival on leaf of oilseed rape (Brassica napus). Acta Phytopathologica Sinica, 30(1). 60-65.

Jiang, M. L., Zhao, R., Hu, X. J., Zhang, Y. B., \& Wang, G. P. (2007). Colonization of antifungal endobacterium BY-2 in oilcrop rape and its control effect on disease caused by Sclerotinia Sclerotiorum. Acta Phytopathologica Sinica, 37(2), 192-196.

Joseph, L. M., Tan, T. K., \& Wong, S. M. (1998). Antifungal effects of hy2 drogen peroxide and peroxidase on spore germination and mycelia grow of Pseudocercospora species. Canadian Journal of Botany, 76(12), 2119-2124. http://dx.doi.org/10.1139/b98-166

Kim, S. Y., Kim, J. Y., \& Kim, S. H. (2007). Surfactin from Bacillus subtilis displays antiproliferative effect via apoptosis induction, cell cycle arrest and survival signaling suppression. FEBS Letters, 581(5), 865-871. http://dx.doi.org/10.1016/j.febslet.2007.01.059

Kloepper, J. W. (1992). A review of issues related to measuring colonization of plant roots by bacteria. Canadian Journal of Microbiology, 38(6), 667-672.

Lamey, H. A. (2003). The status of Sclerotinia sclerotiorum on canola in North America. In Proceedings of Sclerotinia initiative annual meeting. MN, Bloomington.

Li, G. Q., Huang, H. C., \& Acharya, S. N. (2003). Antagonism and biocontrol potential of Ulocladium strumon Sclerotinia sclerotiorum. Biological Control, 28, 11-18. http://dx.doi.org/10.1016/S1049-9644(03)00050-1

Li, H. S. (2000). Principle and technology of plant physiological and biochemical experiments. Beijing: Science Press.

Li, Q. Q., Luo, K., \& Lin, W. (2006). Analysis on the colonization of entophytic bacteria B47 and its control on tomato bacterial wilt. Acta Phytopathologica Sinica, 33(4), 363-368.

Lian, L. L., Xie, L. Y., \& Chen, J. M. (2011). Colonization of biocontrol strain EN5 and its effects on rhizosphere soil microbial communities. Plant Protection, 37(2), 31-35.

Liang, J. F., Xue, Q. H., Niu, X. L., \& Li, Z. B. (2005). Root Colonization and Effects of Seven Strains of Actiomycetes on Leaf PAL and PPO Activities of Capsicum. Acta Bot. Boreal. -Occident. Sin., 25(10), 2118-2123.

Liu, Y. F., Li, M. R., Chen, Z. Y., Yu, J. J., Liu, Y. Z., Lie, Y. F., \& Luo, C. P. (2010). The Inhibition Activities of Isolates YD4-6, NV11-4 and Their Induced Activities to Rice Defense Enzyme. Microbiology China, 37(12), 1753-1759.

Long, L. K., \& Xiao, C. G. (2003). Preliminary study on the colonization of endophytic bacterium 01-144 in tomato root and srem. Microbiology, 30(5), 53-56.

Ma, H. X., Feng, X. J., Chen, Y., Chen, C. J., \& Zhou, M. G. (2009). Occurrence and characterization of dimethachlon insensitivity in Sclerotinia sclerotiorum in Jinagsu Province of China. Plant Dis., 93(1), 36-42. http://dx.doi.org/10.1094/PDIS-93-1-0036

Mueller, D. S., Dorrance, A. E., \& Derksen, R. C. (2002). Efficacy of fungicides on Sclerotinia sclerotiorum and their potential for control of sclerotinia stem rot on soybean. Plant Dis., 86, 26-31. http://dx.doi.org/10.1094/PDIS.2002.86.1.26

Sturz, A. V., Christie, B. R., \& Matheson, B. G. (1997). Biodiversity of endophytic bacteria which colonize red clover nodules, roots, stems and foliage and their influence on host growth. Biol Fertil Soils, 25, 13-19. http://dx.doi.org/10.1007/s003740050273

Sun, J. B., Wang, Y. G., Zhao, P. J., Sun, H. Y., \& Peng, M. (2010). Colonization of Biocontrol Strain XB16 against Fusarium Wilt Pathogen of Banana and Its Effect on Defense-related enzymes. Chinese Journal of Tropical Crops, 31(2), 212-216. 
Tahtamouni, M. E. W., Hammed, K. M., \& Saadoun, I. M. (2006). Biological control of Sclerotinia sclerotiorum using indigenous chitinolytic actinomycete in Jordan. Plant Pathol J, 22, 107-114. http://dx.doi.org/10.5423/PPJ.2006.22.2.107

Volpin, H., Phillips, D. A., \& Okon, Y. (1995). Suppression of an Isoflavonoid Phytoalexin Defense Response in Mycorrhizal Alfalfa Roots. Plant Physiology, 108(4), 1449-1454.

Wang, M. L., Hu, Z. L., \& Zhou, M. Q. (2005). Advances in Research of Polyphenol Oxidase in plants. Chinese Bulletin of Botany, 22(2), 215-222.

Wang, S. R., \& Zhu, K. G. (2002). Advances of research on systemic acquired resistance in plants. Chinese Journal of Eco-Agriculture, 10(2), 32-35.

Wu, J. (2006). The Spatial Distribution of Aculops lycopersici and the Physiological and Biochemical Response of Tomato to Damage. Dissertation, Yangzhou University.

Xue, Y. L., \& Ouyang, G. C. (1992). Metabolic basis of plant disease resistance. Plant physiology and molecular biology. Beijing: Science Press.

Yao, J. (2010). Study on the Biocontrol of Sclerotinia sclerotiorum by Antagonistic Actinomycetes. Dissertation, Sichuan Agricultural University.

Yi, L., Xiao, C. G., \& Ma, G. H. (2007). Antagonistic Endophytic Epiphytic Bacteria, and Their Combination, Induced Tobacco to Resist against Brown Spot Disease. Chinese Journal of Biological Control, 23(2), 165-169.

Zhao, J. W., Xiang, L., \& He, F. X. (1998). Relationship between some enzyme activity and resistance to Sclerotinia sclerotiorum of new strain selected by intergeneric hybridization in Brassica napus. Chinese Journal of Oil Crop Sciences, 20(1), 38-41. http://dx.doi.org/10.1046/j.1439-0523.2003.00784.x

Zhao, J., \& Meng, J. (2003). Detection of loci controlling seed glucosinolate content and their association with Sclerotinia resistance in Brassica napus. Plant Breed, 122(1), 19-23.

Zucchi, T. D., Almeida, L. G., Dossi, F. C. A., \& Fernando, L. C. (2010). Secondary metabolites produced by Propionicimnas sp. (ENT-18) induce histological abnormalities in the sclerotia of Sclerotinia sclerotiorum. Biocontrol, 55(6), 811-819. http://dx.doi.org/10.1007/s10526-010-9295-9

\section{Copyrights}

Copyright for this article is retained by the author(s), with first publication rights granted to the journal.

This is an open-access article distributed under the terms and conditions of the Creative Commons Attribution license (http://creativecommons.org/licenses/by/3.0/). 